\title{
Microbiological Diversity in an Aerated Lagoon Treating Kraft Effluent
}

\author{
Jackeline Valendolf Nunes, ${ }^{\text {a,* }}$ Mac Wendell Barbosa da Silva, ${ }^{\mathrm{a}}$ Gustavo Henrique \\ Couto, ${ }^{a}$ Eduarda Roberta Bordin, ${ }^{a}$ Wanessa Algarte Ramsdorf, ${ }^{a}$ Izadora Cervelin Flôr, ${ }^{\mathrm{b}}$ \\ Vânia Aparecida Vicente, ${ }^{\mathrm{b}}$ José Daniel de Almeida,${ }^{\mathrm{c}}$ Fernanda Celinski, ${ }^{\mathrm{c}}$ and Claudia \\ Regina Xavier ${ }^{\text {a }}$
}

\begin{abstract}
The microbiological diversity of cultivable bacteria was analyzed in an aerated facultative lagoon. The removal of specific compounds and measures of pollutant load was evaluated with isolated native bacteria, selected and identified in kraft cellulose effluent. The system was operated with an organic loading rate of $0.2 \mathrm{kgCODm}^{-3} \mathrm{~d}^{-1}$ for 60 days. Analyses of the fluorescence excitation-emission matrix, acute ecotoxicity, and microbiology were performed. Bioaugmentation tests were done to emphasize the removal of color, using promising species. The removals of biochemical oxygen demand, chemical oxygen demand, and total organic carbon in AFL were $94 \%, 51 \%$, and $41 \%$, respectively. Regarding color, removal was up to $4 \%$, and the total phenolic compounds were not removed through biological treatment. The treatment also decreased turbidity by $94 \%$ and lignin derivatives by $12 \%$. The bacteria identified through NCBI-BLAST and statistical similarity totaled 9 species in the cellulose effluent, three of which have the potential for color treatment: Bacillus cereus, Bacillus thuringiensis, and Paenibacillus sp. The Bacillus cereus combined with biomass removed color (69\%), total phenolic compounds (37\%), and compounds derived from lignin (53\%). These species are promising for removing specific parameters combined with biomass from biological AFL treatment systems.
\end{abstract}

Keywords: Aerated facultative lagoon; Bioaugmentation; Biological treatment; Kraft effluent; Pulp and paper mill; Recalcitrant compounds

Contact information: a: Academic Department of Chemistry and Biology, Federal Technological University of Paraná, Dep. Heitor Alencar Furtado Street, 5000 - Cidade Industrial de Curitiba, Curitiba - Paraná, Brazil; b: Department of Basic Pathology, Federal University of Paraná, Av. Cel. Francisco H. dos Santos, 100 - Jardim das Américas, Curitiba - Paraná, Brazil; c: Cocelpa CIA. of Cellulose and Paper of Paraná, Rodovia do Xisto, S/N - Km 14,5 - Jardim Alvorada, Araucária - Paraná, Brazil;

*Corresponding author: jacke.valendolf@hotmail.com

\section{INTRODUCTION}

The pulp and paper industry is important for the global and Brazilian economies (Ibá 2020). Pulp and paper production requires high water consumption, using 22 to $40 \mathrm{~m}^{3}$ per ton of pulp produced (Hubbe et al. 2016; Ibá 2020). The resulting effluents lead to environmental contamination due to the concentration of organic matter and compounds that are difficult to degrade (Kamali and Khodaparast 2015; Peitz and Xavier 2020). Cellulose effluent is treated in various ways, including biological systems, physicalchemical processes, adsorption, advanced oxidation, and membrane filtration (Majumdar et al. 2019). Except for the biological ones, these methods are expensive, which often makes their application unfeasible (Kamali and Khodaparast 2015; Kamali et al. 2019). 
Table 1. Bacterial Species Identified in the Biological Treatment of Effluent from the Pulp and Paper Industry

\begin{tabular}{|c|c|c|c|c|c|}
\hline Treatment system & Operational conditions & Microorganisms & Parameters & Efficiency (\%) & Authors \\
\hline N.i. ${ }^{1}$ & $\begin{array}{c}\mathrm{pH}: 7.0 \text { to } 8.0 \\
\text { Temperature: } 35^{\circ} \mathrm{C} \\
\text { Agitation: } 140 \mathrm{rpm} \\
\text { HRT: } 7 \mathrm{~d}\end{array}$ & $\begin{array}{l}\text { Serratia marcescens } \\
\text { Serratia liquefaciens } \\
\quad \text { Bacillus cereus }\end{array}$ & $\begin{array}{l}\text { LC } \\
\text { Color } \\
\text { COD } \\
\text { BOD5 }\end{array}$ & $\begin{array}{l}95 \\
65 \\
63 \\
64 \\
\end{array}$ & Chandra et al. 2012 \\
\hline N.i. ${ }^{1}$ & $\begin{array}{c}\text { pH: } 7.6 \\
\text { Temperature: } 34^{\circ} \mathrm{C} \\
\text { Agitation: } 120 \mathrm{rpm} \\
\text { HRT: } 6 \mathrm{~d}\end{array}$ & Paenibacillus sp. & $\begin{array}{l}\text { TPC } \\
\text { LC } \\
\text { Color } \\
\text { BOD }_{5} \\
\text { COD }\end{array}$ & $\begin{array}{l}86 \\
54 \\
68 \\
83 \\
78 \\
\end{array}$ & Raj et al. 2014 \\
\hline Semi-batch reactor ${ }^{2}$ & $\begin{array}{c}\mathrm{pH}: 6.5 \\
\text { Temperature: } 45^{\circ} \mathrm{C} \\
\text { Agitation: } 150 \mathrm{rpm} \\
\text { HRT: } 2.6 \mathrm{~d}\end{array}$ & Bacillus cereus & $\begin{array}{l}\text { Color } \\
\text { COD } \\
\text { BOD }_{5}\end{array}$ & $\begin{array}{l}90 \\
61 \\
66\end{array}$ & Saleem et al. 2014 \\
\hline Aerated lagoon ${ }^{1}$ & $\begin{array}{c}\mathrm{pH}: 7.4 \text { to } 7.8 \\
\text { Temperature: } 20^{\circ} \mathrm{C} \\
\text { HRT: not informed }\end{array}$ & $\begin{array}{c}\text { Bacillus thuringiensis } \\
\text { Bacillus subtilis } \\
\text { Runella sp. } \\
\text { Legionella sp. }\end{array}$ & - & - & $\begin{array}{c}\text { Bailón-Salas et al. } \\
\qquad 2017\end{array}$ \\
\hline Semi-batch reactor ${ }^{2}$ & $\begin{array}{c}\mathrm{pH}: 7.0 \text { to } 8.2 \\
\text { Temperature: } 35^{\circ} \mathrm{C} \\
\text { HRT: } 1.3 \mathrm{~d}\end{array}$ & Brevibacillus parabrevis & $\begin{array}{l}\text { LC } \\
\text { Color } \\
\text { COD }\end{array}$ & $\begin{array}{l}42 \\
51 \\
60\end{array}$ & Hooda et al. 2018 \\
\hline $\begin{array}{l}\text { Sequential batch } \\
\text { reactor }^{1}\end{array}$ & $\begin{array}{c}\text { pH: } 7.0 \\
\text { Temperature: } 37^{\circ} \mathrm{C} \\
\text { HRT: } 3 \mathrm{~d}\end{array}$ & Bacillus sp. & $\begin{array}{l}\text { AOX } \\
\text { TPC } \\
\text { LC } \\
\text { Color } \\
\text { TOC } \\
\text { COD } \\
\text { BOD } 5 \\
\end{array}$ & $\begin{array}{l}75 \\
88 \\
64 \\
73 \\
82 \\
86 \\
93 \\
\end{array}$ & Sonkar et al. 2019 \\
\hline
\end{tabular}


Activated sludge and aerated facultative lagoon (AFL) processes are the most used systems in the biological treatment of effluents from the pulp and paper industry (Kamali and Khodaparast 2015; Bailón-salas et al. 2017; Lewis et al. 2018). In this sense, AFLs are widely used in Brazil due to the country's favorable climatic conditions and the large availability of area for the construction of these lagoons (Von Sperling 2016).

In addition, AFLs are simple to maintain, have low cost, and remove the biochemical oxygen demand (BOD5 between 80 and 95\%) and the chemical oxygen demand (COD between 40 and 60\%) in different types of effluents. Aerated facultative lagoons are stable in relation to shock loads, distributing the excess over their length, and have long hydraulic retention time (HRT) (2 to 10 days) (Swamy et al. 2011; Subashini 2015). In kraft effluents, lignin compounds and their derivatives persist in the cellulose effluent because of their recalcitrance. Therefore, efforts have been made to optimize this process for the removal of these specific compounds (Machado et al. 2018).

The bioaugmentation is based on the spontaneous and controlled action of microorganisms to increase their quantity and be able to degrade pollutants from soil, water bodies, and industrial effluents process (Ardeleanu 2011). This process is an alternative to improving the performance of AFL treatment in the removal of specific compounds, and it is a sustainable technology with a good benefit-cost ratio (Hossain and Ismail 2015). The challenge is to select the best microorganism to degrade the specific compounds in pulp industry effluents (Ghribi et al. 2016; Bailón-salas et al. 2017). Table 1 lists studies with specific bacteria used to remove recalcitrant compounds present in cellulose effluents, such as lignin compounds (LC) and their derivatives, aromatic compounds (AC), total phenolic compounds (TPC), and color, which show the efficiency in the use of bacteria for such treatment.

Among the microorganisms found in aerobic biological treatment systems are Bacillus sp., Brevibacillus parabrevis, Paenibacillus sp., and Serratia liquefaciens, which are efficient in the degradation of specific and hard-to-degrade compounds contained in cellulose effluents (Hooda et al. 2018; Singh et al. 2019; Sonkar et al. 2019).

The objective of this research was to evaluate the bacterial diversity in an AFL system with an organic loading rate (OLR) of $0.2 \mathrm{kgCODm}^{-3} \mathrm{~d}^{-1}$ and the removal of specific compounds through bioaugmentation with isolated native bacteria, selected and identified contained in kraft cellulose effluent.

\section{EXPERIMENTAL}

\section{Effluent Sample Collection}

The AFL influent was provided by an unbleached kraft pulp mill based in the metropolitan region of Curitiba, in the state of Paraná, Brazil. The samples were collected at the entrance of the treatment system, before primary settling basin, which is followed by biological treatment through aerated facultative and maturation lagoons. The samples were transported in $20 \mathrm{~L}$ containers and stored at $4{ }^{\circ} \mathrm{C}$ in the absence of light (Apha 2017). For treatment in the AFL, two sample collections were performed (Sample 1), and for bioaugmentation tests, a third sample (Sample 2) was collected.

\section{Laboratory-scale aerated facultative lagoon}

The AFL treatment was operated for $60 \mathrm{~d}$ with an OLR of $0.2 \mathrm{kgCODm}^{-3} \mathrm{~d}^{-1}$, and the addition of nutrients to the AFL influent remained in the proportion of 100:0.5:0.1 for 
COD:N:P, based on the ratio applied by the mill that provided the samples. The concentration of inoculated sludge was $70 \mathrm{mgL}^{-1}$ (Von Sperling 2014). A Lutron Oxygen Meter DO-5519 (Taipei, Taiwan) was used in order to measure dissolved oxygen (DO), ICEL OR-2300 (Haifa, Israel) was used for redox potential (RP), and pH Meter CienlaB mPA-210 (Piracicaba, Brazil) for the $\mathrm{pH}$. The system developed in laboratory conditions is represented in Fig. 1.

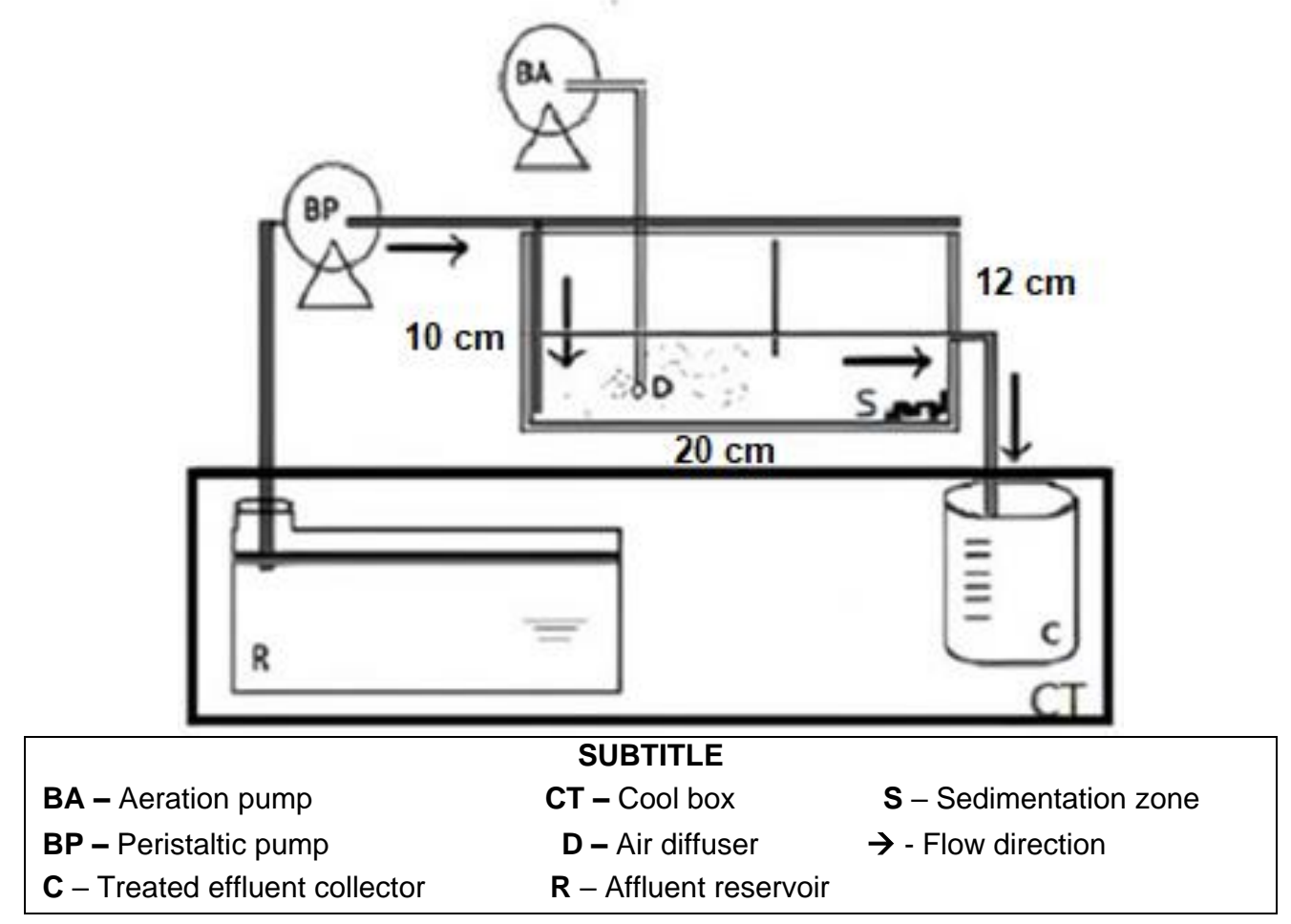

Fig. 1. Bench AFL scheme

\section{Characterization of cellulose effluent samples}

The sample provided by the industry and also the influent and effluent from AFL treatment were analysed. The samples were filtered with a nitrocellulose filter of $0.45 \mu \mathrm{m}$ pore size and analyzed using the parameters of BOD5, COD, TOC, color (Vis440nm), turbidity, TPC, aromatic compounds ( $\left.\mathrm{UV}_{254 \mathrm{~nm}}\right)$, and compounds derived from lignin, that is, lignins (UV280nm) and lignosulfonic ones (UV346nm) (Çeçen 2003; Chamorro et al. 2009; Apha 2017). The color sample was analyzed at $\mathrm{pH} \mathrm{9.0,} \mathrm{and} \mathrm{the} \mathrm{sample} \mathrm{of} \mathrm{aromatic}$ compounds and lignin derivatives was analyzed at pH 7.0 (Çeçen 2003), both using a Varian UV-VIS Cary-50 Spectrophotometer (Santa Clara, United States of America). All analyses were performed in triplicate.

In addition, the following analyses were also performed when the AFL reached steady-state: Fluorescence excitation-emission matrix (EEM), total and volatile suspended solids (TSS and VSS) on the biomass, and acute ecotoxicity of both the influent and effluent of the treatment with Daphnia magna (ABNT NBR 12713 2016).

\section{Microbiological Diversity Analysis}

Microbiological analyses were performed on biomass samples taken from the AFL at steady-state and guided by molecular identification based on 16S rRNA gene sequence analysis. First, bacteria were isolated from biomass using nutrient agar medium (Himedia, 
Mumbai, Índia) after incubation of plates at $30^{\circ} \mathrm{C}$ for $48 \mathrm{~h}$. Genomic DNA was extracted and purified from isolates in the kraft effluent (Vicente et al. 2008) and 16S rRNA gene was amplified by polymerase chain reaction (PCR) using the universal primers 968F/1392R for the bacteria domain. Afterwards, PCR fragments were analyzed by electrophoresis through $1 \%$ agarose gels for $16 \mathrm{~S}$ rRNA products followed by purification and sequencing on a Illumina MiSeq platform using the MiSeq Reagent Kit v3 600 (San Diego, USA).

Bacteria were identified by sequence alignment using the nucleotide Basic Local Alignment Search Tool (BLASTN) against the nucleotide collection database (NCBI database, https://blast.ncbi.nlm.nih.gov/Blast.cgi).

\section{Bioaugmentation Test}

The bioaugmentation test was performed as presented by Saleem et al. (2014). Initially, Bacillus cereus, Bacillus thuringiensis, and Paenibacillus sp. were plated; subsequently, $2 \mathrm{~mL}$ of the solution of each isolated species were added to a $250 \mathrm{~mL}$ Erlenmeyer flask containing $20 \mathrm{~mL}$ of nutrient broth. These were stirred at $40 \mathrm{rpm}$ in a shaker at $30{ }^{\circ} \mathrm{C}$, and their growth was monitored every $1 \mathrm{~h}$ through the optical density analysis of the samples using a UV-Vis spectrophotometer at a wavelength of $600 \mathrm{~nm}$ (Bombardi et al. 2018). The results of these measurements were analyzed using the Chem Agilent software to determine the concentration of the colony-forming unit (CFU mL $\left.{ }^{-1}\right)$.

In the bioaugmentation process, the combinations shown in Fig. 2 were under aeration and agitation at $70 \mathrm{rpm}$ in a shaker, at a temperature of $25^{\circ} \mathrm{C}$, for $2.1 \mathrm{~d}$ in order to have OLR conditions similar to those of the AFL with $0.2 \mathrm{kgCODm}^{-3} \mathrm{~d}^{-1}$. In experiments containing biomass, $70 \mathrm{mg} \mathrm{VSS} \mathrm{L}^{-1}$ was used in each system. The influent of each system was $100 \mathrm{~mL}$ of the sample from the kraft pulp mill, with $\mathrm{pH}$ adjusted to 7.0 (0.02) and addition of nutrients for COD:N:P of 100:0.5:0.1. Figure 2 shows a flowchart with the layout of the tests for the bioaugmentation treatment.
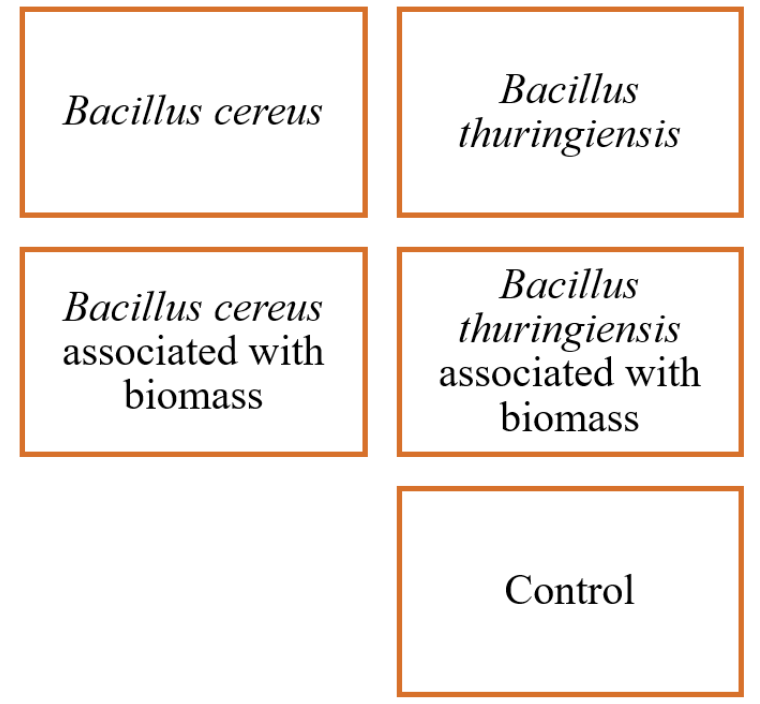
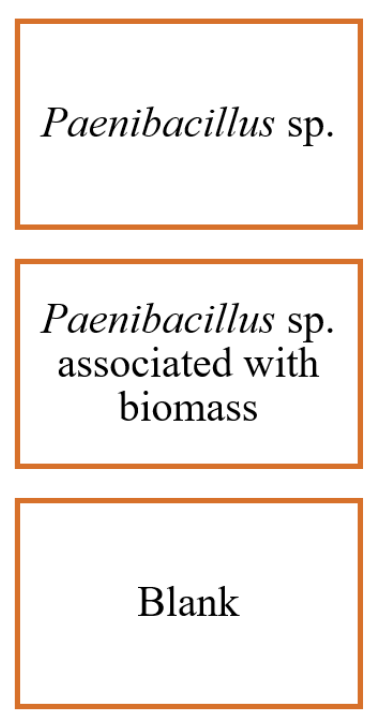
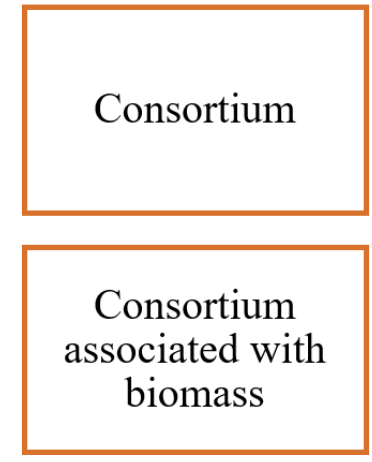

Fig. 2. Layout of bioaugmentation tests

The isolated bacteria, isolated bacteria combined with biomass, consortium, and consortium combined with biomass were tested in triplicate. A blank was carried out containing only neutralized influent with the addition of nutrients, while in the control, in 
addition to the aforementioned content, $70 \mathrm{mgVSSL}^{-1}$ of biomass were present.

The efficiency of the treatment was evaluated according to the removal of BOD5, COD, TPC, color, aromatic compounds, and compounds derived from lignin, that is, lignin and lignosulfonic compounds.

\section{RESULTS AND DISCUSSION}

\section{Sample Characterization}

Results for characterization of Samples 1 and 2 provided by the pulp mill are shown in Table 2. Sample 1 was used during the treatment with OLR of $0.2 \mathrm{~kg} \mathrm{COD} \mathrm{m}^{-3} \mathrm{~d}^{-1}$, and Sample 2, in the bioaugmentation test. The influent of Sample 1 presented a BOD $/$ COD ratio of 0.28 and Sample 2 of 0.33. According to Jordão and Pessoa (2016), the values above 0.30 suggest good biodegradability, being favorable for biological treatment.

Table 2. Characterization of the Cellulose Industry Sample

\begin{tabular}{|c|c|c|}
\hline Parameters & Sample I $(\mathbf{n}=\mathbf{2})$ & Sample II (n = 1) \\
\hline $\mathrm{pH}$ & $7.50(0.20)$ & $7.32(0.10)$ \\
\hline $\mathrm{COD}\left(\mathrm{mg} \mathrm{L}^{-1}\right)$ & $440.89(4.80)$ & $360.00(3.50)$ \\
\hline $\mathrm{BOD}_{5}\left(\mathrm{mg} \mathrm{L}^{-1}\right)$ & $124.74(2.70)$ & $120.40(2.10)$ \\
\hline $\left.\mathrm{BOD} / \mathrm{COD}^{-1}\right)$ & 0.28 & 0.33 \\
\hline $\mathrm{TOC}\left(\mathrm{mg} \mathrm{L}^{-1}\right)$ & $102.47(2.19)$ & - \\
\hline $\mathrm{TPC}\left(\mathrm{mg} \mathrm{L}^{-1}\right)$ & $174.82(3.40)$ & $295.11(3.24)$ \\
\hline Color $\left(\mathrm{Vis}_{440 \mathrm{~nm}}\right)$ & $0.31(0.10)$ & $0.28(0.01)$ \\
\hline $\mathrm{AC}\left(\mathrm{UV}_{254 \mathrm{~nm}}\right)$ & $2.65(0.24)$ & $2.83(0.01)$ \\
\hline $\mathrm{LC}\left(\mathrm{UV}_{280 \mathrm{~nm}}\right)$ & $2.85(0.30)$ & $2.50(0.49)$ \\
\hline $\mathrm{LSC}\left(\mathrm{UV}_{346 \mathrm{~nm}}\right)$ & $1.05(0.25)$ & $0.78(0.09)$ \\
\hline
\end{tabular}

The values presented in the table are averages of the results obtained from the characterization analyzes of the tributary used during the treatment, carried out in triplicate. In parentheses are the standard deviations of these results. $n$ - number of samples, LSC - lignosulfonic compounds.

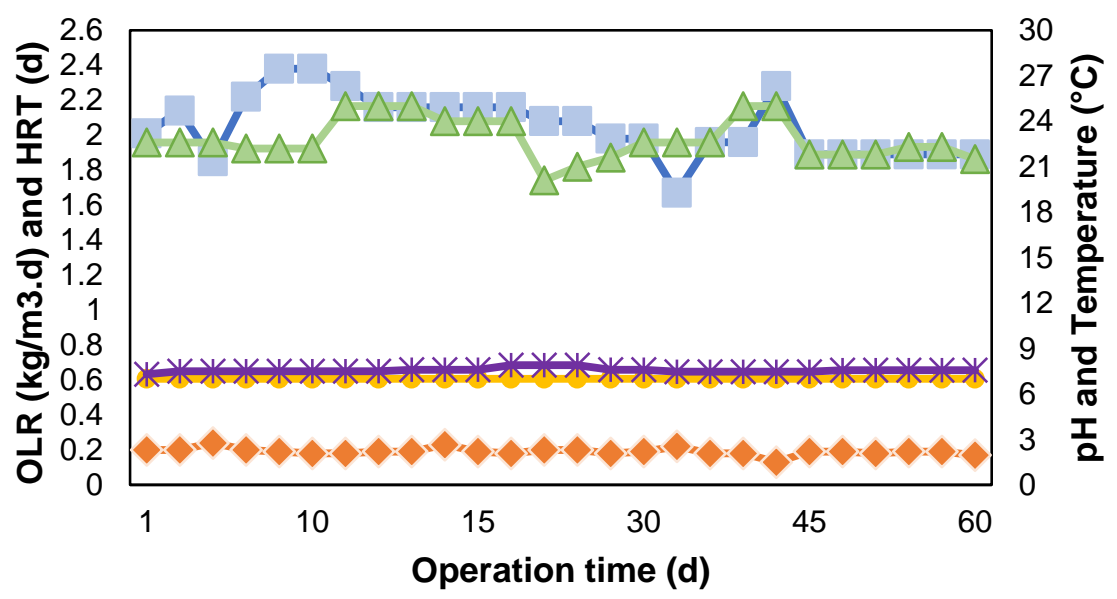

$$
- \text { HRT }- \text { OLR } \triangle \text { Temperature } \longrightarrow \mathrm{pH}(\mathrm{a}) \rightarrow \mathrm{pH}(\mathrm{e})
$$

Fig. 3. Control parameters of AFL. OLR, organic loading rate; HRT, hydraulic retention time 


\section{AFL operating parameters}

Figure 3 contains data on the AFL control parameters in relation to organic loading rate, $\mathrm{pH}$, temperature, and hydraulic retention time. The average organic loading rate was $0.19(0.02) \mathrm{kgCODm}^{-3} \mathrm{~d}^{-1}$, which is close to the predicted value that resulted in an average HRT of $2.1 \mathrm{~d}$. The average temperature was $23.0^{\circ} \mathrm{C}$. The influent $\mathrm{pH}$ was set at 7.0 to enter the AFL treatment system; however, the average $\mathrm{pH}$ measured in the treatment effluent was 7.4. The RP measured in the AFL aerated zone was $42.0 \mathrm{mV}$, while in the sedimentation zone it was $-23.5 \mathrm{mV}$, which is in line with the AFL system, in which an anoxic environment is observed in the sedimentation zone (Metcalf and Eddy 2016).

\section{Evaluation of organic matter removal}

Figure 4 shows the organic matter removal in terms of BOD5 and COD. The average values of BOD5 removal were greater than $90 \%$, which is in line with previous reports, 50 to $95 \%$ of BOD5 removal in systems and conditions similar to those employed in this study (Machado et al. 2018; Peitz and Xavier 2020).

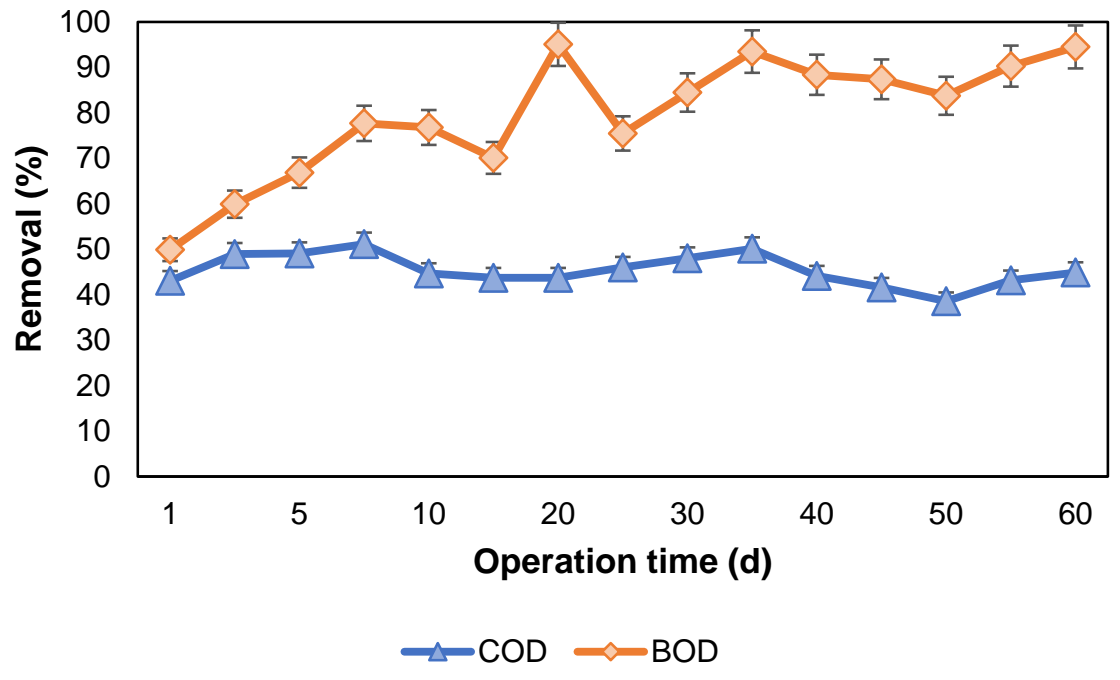

Fig. 4. Removal of organic matter in relation to $\mathrm{BOD}_{5}$ and $\mathrm{COD}$

The COD removal ranged between 40 and $60 \%$ during the $60 \mathrm{~d}$ of operation. This result was similar to that obtained by Machado et al. (2018) using the organic load rate of $0.2 \mathrm{kgCODm}^{-3} \mathrm{~d}^{-1}$ in an aerated lagoon. Hubbe et al. (2016) and Kamali et al. (2019) reported the difficulty that biological systems present in treating cellulose effluents because the efficiency of COD removal is usually around $50 \%$.

The analysis of TOC removal averaged $49 \%$ for the AFL with OLR of 0.2 $\mathrm{kgCODm}^{-3} \mathrm{~d}^{-1}$. The results obtained in such OLR were similar to the result found by Lewis et al. (2018) in an aerated facultative lagoon.

In the state of Paraná, Brazil, the Conselho Estadual do Meio Ambiente [State Council for the Environment] (CEMA) establishes that for the pulp and paper industry, the limit of BOD 5 in the effluent discharged into water bodies should be $50 \mathrm{mg} \mathrm{L}^{-1}$, and the COD should be $300 \mathrm{mg} \mathrm{L}^{-1}$ (CEMA Resolution 070/2009). Thus, the treatment performed was effective in adapting the effluent to the discharge criteria based on global organic matter. 
Evaluation of the AFL specific compounds, color, and turbidity

Figure 5 presents the analysis of specific compounds, namely: total phenolic compounds, aromatic compounds, lignin compounds, lignosulfonic compounds, in addition to the AFL color and turbidity parameters.

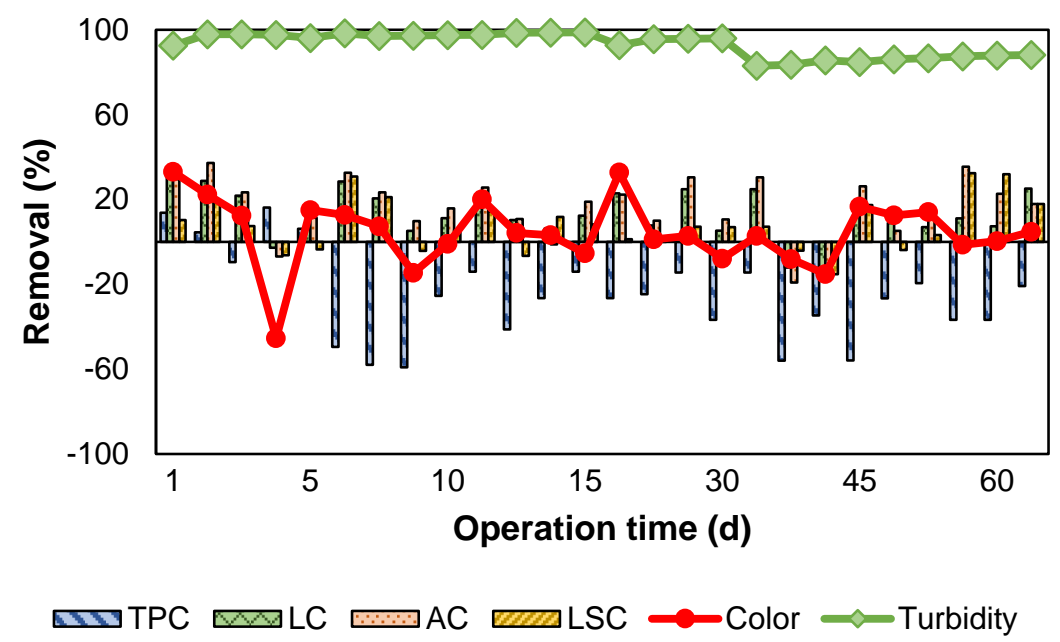

Fig. 5. Evaluation of removal of specific compounds, color, and turbidity

Figure 5 shows that the TPC increased during the AFL treatment with an average of $26 \%$. Some studies with kraft effluent showed an increase in total phenolic compounds in aerated biological systems (Chamorro et al. 2009; Duarte et al. 2018; Machado et al. 2018; Melchiors 2019; Peitz and Xavier 2020).

In relation to the other specific compounds of the kraft cellulose effluent, the removal of lignin compounds was around 13\%. For aromatic compounds, the average removal was $16 \%$, and the lignosulfonic compounds had an average removal of $8 \%$.

The data verified that there was no color removal. The increase observed in the first $10 \mathrm{~d}$ of operation is related to the stabilization of the treatment system. The increase in color may be related to the process of biotransformation of chromophoric units and the condensation of color-forming compounds, without mineralization of the effluent (Lewis et al. 2018; Peitz and Xavier 2020). Low color removal has been observed during treatment by aerated lagoons (Kamali and Khodaparast 2015; Peitz and Xavier 2020).

Regarding the removal of turbidity, the system showed an average removal of $94 \%$. In general, the AFL system showed good removal in this parameter, indicating potential for clarification of the effluent in the AFL sedimentation zone.

\section{$C: N: P$ ratio and the performance of aerated lagoons}

In relation to the $\mathrm{C}: \mathrm{N}: \mathrm{P}$ ratio used, the AFL efficiency used in this study was compared with studies using different nutrient ratios. Table 3 shows the performance of aerated lagoons treating kraft cellulose effluent with different COD:N:P ratios.

In the studies by Machado et al. (2018) and Peitz and Xavier (2020), the nutrient ratio was 100:5:1; in the present study, it was 100:0.5:0.1, which is more similar to that of an AFL and to what is actually employed by the industry. The removal of biodegradable organic matter $\left(\mathrm{BOD}_{5}\right)$ was greater in this study than in those with more use of nutrients. The lower color removal, however, may be associated with low redox potential in the AFL 
sedimentation zone. In general, it was observed that the demand for nutrients can be optimized, which can result in savings in the treatment process.

Table 3. Comparison of Removal of Parameters

\begin{tabular}{|c|c|c|c|}
\hline \multicolumn{3}{|c|}{ Removal (\%) } \\
\hline Parameters & $\mathbf{1 0 0 : 0 . 5 : 0 . 1 ^ { 1 }}$ & $\mathbf{1 0 0 : 5 : \mathbf { 1 } ^ { 2 }}$ & $\mathbf{1 0 0 : 5 : \mathbf { 1 } ^ { 3 }}$ \\
\hline BOD $\left(\mathrm{mg} \mathrm{L}^{-1}\right)$ & 94 & 87 & 75 \\
\hline COD $\left(\mathrm{mg} \mathrm{L}^{-1}\right)$ & 51 & 52 & 50 \\
\hline TOC $\left(\mathrm{mg} \mathrm{L}^{-1}\right)$ & 49 & - & - \\
\hline TPC $\left(\mathrm{mg} \mathrm{L}^{-1}\right)$ & -26 & 24 & -20 \\
\hline Color $\left(V_{4} 440 n m\right)$ & 4 & 7 & 12 \\
\hline LC $\left(\mathrm{UV}_{280 n m}\right)$ & 13 & 18 & 16 \\
\hline Turbidity (NTU) & 94 & 97 & - \\
\hline DO $\left(\mathrm{mg} \mathrm{L}^{-1}\right)$ & 3.9 & 6.3 & 4.0 \\
\hline
\end{tabular}

${ }^{1}$ in this research, ${ }^{2}$ Machado et al. (2018), ${ }^{3}$ Peitz and Xavier (2020). The values presented in the table are averages of the results obtained from the analyzes during the treatment. NTU nephelometric turbidity units, Negative values indicate an increase in the parameter.

Analysis of fluorescence excitation-emission matrix (EEM)

Figure 6 shows the fluorescence excitation-emission matrices (EEM) of the treatment system. Fluorescence intensity (FI) is expressed in arbitrary units (a.u.).
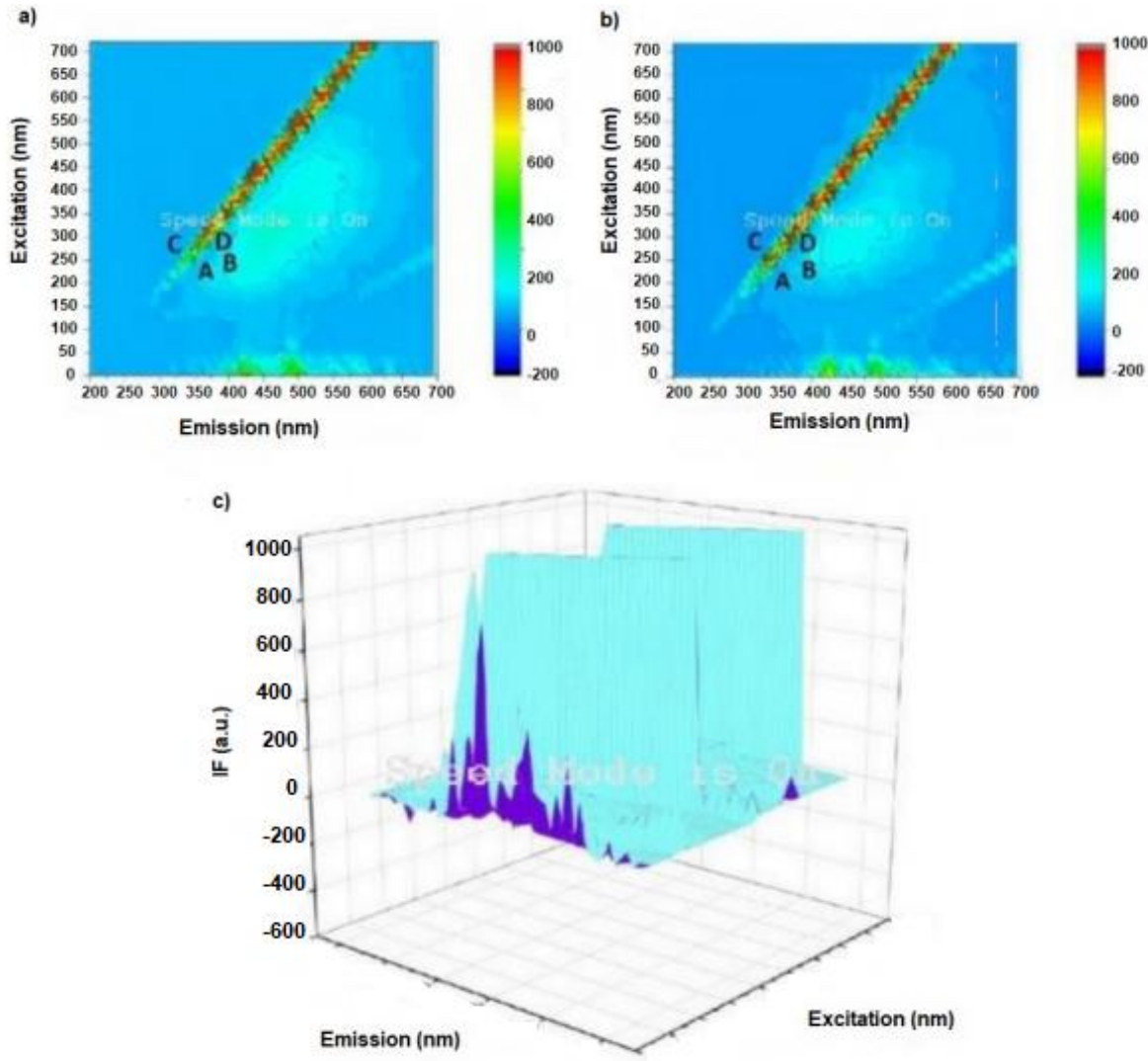

Fig. 6. Fluorescence excitation-emission matrices of the treatment system by LAF a) EEM's affluent, b) EEM's effluent, c) 3D spectrum of fluorescence intensity (FI) of the fluorogenic compounds removed and increased during treatment in the AFL system 
Figures $6 \mathrm{a}$ and $6 \mathrm{~b}$ show different fluorescence peaks, represented by excitation $\left(\lambda_{\mathrm{EX}}\right)$ and emission $\left(\lambda_{\mathrm{EM}}\right)$ wavelengths. The observed peaks were named A, B, C, and D. Peaks A and B, located in the $\lambda_{\mathrm{EM}}<380 \mathrm{~nm}$ region, were identified by Carstea et al. (2016) in several EEMs obtained from wastewater. These peaks are associated with by-products of organic matter biodegradation (Bridgeman et al. 2013). Peak C is related to the common chemical characteristics of cellulose industry effluents, such as compounds derived from lignin (Managó 2019). Peak D is related to fluorogenic compounds. Comparing Fig. 6a and $6 \mathrm{~b}$, it is possible to observe a small removal of the aforementioned compounds.

Figure $6 \mathrm{c}$ shows the 3D spectrum of the difference between the fluorescence intensity emitted by the AFL influent and effluent. The peaks of positive FI represent the fluorogenic compounds removed in the treatment, and negative FI indicates the intensity increased during the treatment (Melchiors 2019). The presentation of this spectrum corroborates the results of the present research, such as color production in the anoxic zone, TPC in the aerated zone, and the low removal of lignin derivatives. Other authors have also encountered the removal of fluorogenic compounds in cellulose effluents (Janhom et al. 2011; Murphy et al. 2011; Carstea et al. 2016; Melchiors 2019).

\section{Biomass analysis}

Regarding the biomass of the treatment system, it was observed that after $60 \mathrm{~d}$ of operation in the lagoon, the VSS reached $770 \mathrm{mg} \mathrm{L}^{-1}$ and the TSS was $1181 \mathrm{mg} \mathrm{L}^{-1}$. The average VSS/TSS ratio was 0.67 , which indicates a stabilized biomass (Von Sperling 2014). The observed growth rate was $1100 \%$ and is comparable to that observed by Peitz 2018, in which the biomass grew from $70 \mathrm{mg} \mathrm{L}^{-1}$ of VSS to $1783 \mathrm{mg} \mathrm{L}^{-1}$ in 60 days of operation in an aerated lagoon, containing support medium with an OLR similar to the one in the present study.

\section{Ecotoxicity analysis}

The results of acute ecotoxicity were carried out with Daphnia magna with a $48 \mathrm{~h}$ exposure to the influent and the effluent treated by AFL. The toxicity factor obtained was $1(\mathrm{TF}=1)$, which shows that the sample of effluent obtained from the pulp and paper industry did not present acute toxicity even at $100 \%$ concentration. These results are in line with those found by Machado et al. (2018) and Peitz and Xavier (2019) with Daphnia magna exposed to the same type of effluent. Thus, these data comply with the current state legislation by CEMA, resolution No 081/10 (CEMA Resolution 081/2010 (2010).).

\section{Identification of Bacteria Contained in the Effluent}

The comparison of the $16 \mathrm{~S}$ rRNA gene sequences of the bacteria were carried out against the NCBI database to find regions of identity with statistical significance between deposited sequences. Table 4 shows the isolated bacteria identified ( $\geq 97 \%$ of query coverage) in the biomass of the AFL treating kraft pulp effluent. The total number of microorganisms collected from the aerated and sedimentation zones was 9, which were species of bacteria, as shown in Table 4.

The microorganisms identified in the AFL biomass have also been found in other studies with bacteria, such as the ones by Chandra et al. (2012), Raj et al. (2014), Saleem et al. (2014), Bailón-Salas et al. (2017), and Sonkar et al. (2019). Among such microorganisms, there was an emphasis on Bacillus cereus as promising for color removal in cellulose effluent, as suggested by Saleem et al. (2014). 
Table 4. Bacteria Identified in the AFL

\begin{tabular}{|c|c|c|c|c|c|}
\hline $\begin{array}{c}\text { Anaerobic } \\
\text { Zone }\end{array}$ & $\begin{array}{c}\text { NCBI } \\
\text { Accession } \\
\text { Number }\end{array}$ & $\begin{array}{c}\text { Percent } \\
\text { Identity } \\
(\%)\end{array}$ & Aerated Zone & $\begin{array}{c}\text { Percent } \\
\text { Identity } \\
(\%)\end{array}$ & $\begin{array}{c}\text { NCBI } \\
\text { Accession } \\
\text { Number }\end{array}$ \\
\hline $\begin{array}{c}\text { Acinetobacter } \\
\text { junii }\end{array}$ & AJ786647.1 & 98 & - & - & \\
\hline $\begin{array}{c}\text { Bacillus } \\
\text { anthracis }\end{array}$ & NR_041248.1 & 99 & - & - & NR_114581.1 \\
\hline Bacillus cereus & AB050631.1 & 98 & - & - & NR_115590.1 \\
\hline $\begin{array}{c}\text { Bacillus } \\
\text { thuringiensis }\end{array}$ & NR_114581.1 & 98 & $\begin{array}{c}\text { Bacillus } \\
\text { thuringiensis }\end{array}$ & 97 & NR_118146.1 \\
\hline $\begin{array}{c}\text { Cytobacillus } \\
\text { kochii }\end{array}$ & MW358143.1 & 98 & $\begin{array}{c}\text { Brevibacillus } \\
\text { choshinensis }\end{array}$ & 98 & $\begin{array}{c}\text { Lysinibacillus } \\
\text { mangiferihumi }\end{array}$ \\
\hline $\begin{array}{c}\text { Paenibacillus } \\
\text { sp. }\end{array}$ & NR_115597.1 & 97 & 98 & - & \\
\hline $\begin{array}{c}\text { Sphingomonas } \\
\text { koreensis }\end{array}$ & NR_024998.1 & 97 & - &
\end{tabular}

\section{Bioaugmentation Test}

Subsequently, bioaugmentation tests were performed to emphasize the removal of color, using the following species: Bacillus cereus, Bacillus thuringiensis, and Paenibacillus sp. This parameter was considered to be a challenge for biological treatment due to the processes of depolymerization and molecular repolymerization in the different conditions employed. Following the increase in the concentration of bacteria, it was observed that the maximum growth occurred in $1.5 \mathrm{~h}$ for Bacillus cereus and Bacillus thuringienses, and in $6 \mathrm{~h}$ for Paenibacillus sp. under incubation conditions. The bacteria concentration was $6.2 \times 10^{8}, 6.4 \times 10^{8}$, and $6.3 \times 10^{8} \mathrm{CFU} \mathrm{mL} \mathrm{mL}^{-1}$ for the three species, respectively.

In the bioaugmentation, both organic matter and specific compounds were removed. In Fig. 7, these results are presented from the tests with Bacillus cereus, Bacillus cereus coupled with biomass, Bacillus thuringiensis, Bacillus thuringiensis coupled with biomass, Paenibacillus sp., Paenibacillus sp. coupled with biomass, mixed (Bacillus cereus, Bacillus thuringiensis, and Paenibacillus sp.), mixed coupled with biomass, blank and control.

Despite the performance of Paenibacillus sp. combined with biomass having been the best system for the removal of global organic matter, the treatment of specific compounds, especially color, was better in the system in which Bacillus cereus combined with biomass was used. Under these conditions, besides color (69\%), TPC (37\%), LC (53\%), AC (50\%), and lignosulfonic compounds (49\%) were also removed. In the control test, the use of aeration alone caused an increase in the TPC in the medium, as observed in other studies (Chamorro et al. 2010; Melchiors 2019; Peitz and Xavier 2020).

Regarding the bacteria used in the present study, it is worth mentioning that Saleem et al. 2014 used Bacillus cereus alone for the treatment of cellulose effluent, removing BOD5, COD, and color by $66 \%, 61 \%$, and $90 \%$, respectively, with pH 6.5 in a batch reactor. Chandra et al. (2012) also employed Bacillus cereus in the treatment of cellulose effluent; however, they combined it with Serratia marcescens and Serratia liquifaciens, which had been identified in a cellulose effluent treatment system. They obtained the removal of $65 \%$ for color, $63 \%$ for TPC, $63 \%$ for COD, and 64\% for BOD 5 for a 7-day HRT. With these results, it is possible to affirm that the present bioaugmentation study using Bacillus cereus combined with biomass was close to that observed in the literature. 

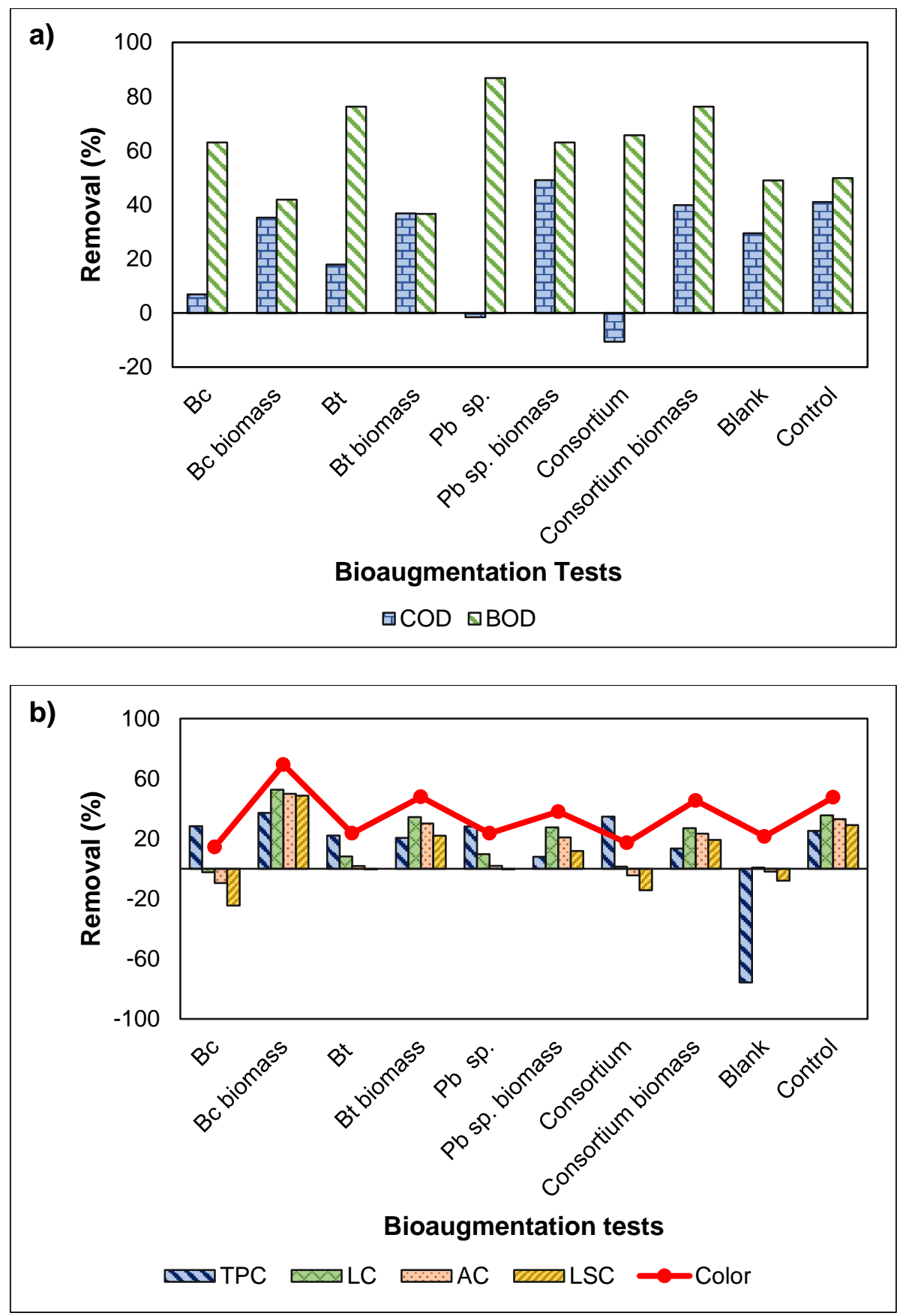

Fig. 7. Evaluation of removal of organic matter and specific compounds in bioaugmentation a) removal of organic matter in $\mathrm{BOD}_{5}$, and $\mathrm{COD}$ b) removal of specific compounds from kraft effluent, $\mathrm{BC}$ - Bacillus cereus $\mathrm{Bt}$ - Bacillus thuringiense $\mathrm{Pb}$ - Paenibacillus $\mathrm{sp}$.

The bacterium Paenibacillus sp. was identified by Raj et al. (2014) in a batch reactor in a 6-day HRT in the treatment of cellulose effluent, in which removals of $68 \%$, $54 \%, 86 \%, 83 \%$, and $78 \%$ were obtained for color, lignin compounds, total phenol, BOD5, and COD, respectively. Chandra et al. (2008) identified the bacteria Bacillus sp. and Paenibacillus sp. in a cellulose effluent treatment system operating with 6-day HRT, $\mathrm{pH}$ of 7.6 and temperature of $30{ }^{\circ} \mathrm{C}$, in which color was removed by $65 \%$ and $48 \%$ for the bacteria used separately in treatment by bioaugmentation. 
Sonkar et al. (2019) identified the bacterium Bacillus thuringiensis in a cellulose effluent treatment system and found a $99 \%$ similarity to it in a batch reactor. The removal of $\mathrm{BOD}_{5}, \mathrm{COD}, \mathrm{TOC}$, and color was by $93 \%, 89 \%, 82 \%$, and $73 \%$, respectively, with a 3day HRT. These species (Bacillus cereus, Bacillus thuringiensis, and Paenibacillus sp.), which were identified and used in the bioaugmentation tests, proved to be promising for removal of specific parameters combined with biomass from AFL biological treatment.

\section{CONCLUSIONS}

1. In this study, the microbiological diversity of a kraft effluent treatment system by an aerated lagoon was analyzed, and 9 species of bacteria were identified, three of which have the potential for color treatment: Bacillus cereus, Bacillus thuringiensis, and Paenibacillus sp.

2. There was efficiency by AFL in removing specific compounds from the kraft effluent with an OLR of $0.2 \mathrm{kgCODm}^{-3} \mathrm{~d}^{-1}$ being in the parameters of $\mathrm{BOD}_{5}(94 \%), \mathrm{COD}(51 \%)$, TOC (49\%). Regarding color, removal was up to $4 \%$, and the total phenolic compounds were not removed through biological treatment. The treatment also decreased turbidity by $94 \%$ and lignin derivatives by $12 \%$.

3. In bioaugmentation tests, the treatment of specific compounds and especially the color was better in the system with Bacillus cereus associated with biomass, in which the removal were to color (69\%), TPC (37\%), LC ( 53\%), AC (50\%) and lignosulfonic compounds $(49 \%)$.

4. The bioaugmentation of the Bacillus cereus with the biomass of the treatment system is a sustainable and innovative alternative for the treatment of kraft effluent in OLR of $0.2 \mathrm{~kg} \mathrm{CODm}^{-3} \mathrm{~d}^{-1}$.

\section{ACKNOWLEDGMENTS}

The authors are grateful to the Cocelpa cellulose and paper supplying the effluent, to the Federal Technological University of Paraná, the Department of Chemistry and Biology, the Wastewater Treatment Laboratory, UTFPR Microbiology Laboratory, Ecotoxicology Laboratory, UFPR Microbiology and Parasitology Laboratory, and the Effluent Treatment Research Group (GTEF) for the support and opportunity to develop this work.

\section{REFERENCES CITED}

ABNT NBR 12713 (2016). "Ecotoxicologia aquática - Toxicidade aguda - Método de ensaio com Daphnia spp. (Cladocera, Crustacea) [Aquatic ecotoxicology - Acute toxicity - Test with Daphnia spp (Cladocera, Crustacea)]," Associação Brasileira de Normas Técnicas, Rio de Janeiro, Brazil.

APHA (2017). Standard Methods for the Examination of Water and Wastewater, $23^{\text {rd }}$

Edition, E. W. Rice, R. B. Baird, A. D. Eaton (eds.), American Public Health 
Association, Washington, D.C.

Ardeleanu, E. R. (2011). “An approach to bioremediation," Journal of Engineering Studies and Research 17(4), 7-12.

Bailón-Salas, A. M., Medrano-Roldán, H., Valle-Cervantes, S., Ordaz-Díaz, L. A., UrtizEstrada, N., and Rojas-Contreras, J. A. (2017). "Review of molecular techniques for the identification of bacterial communities in biological effluent treatment facilities at pulp and paper mills," BioResources 12(2), 4384-4409. DOI:

10.15376/biores.12.2.Bailon_Salas

Bombardi, F. M. L., Ishii, F. K., Pelayo, J. S., Kolm, H. E., Müller, M., and Fabris, J. L. (2018). "Spectral monitoring of the growth dynamics of E. coli bacterial populations in water environment," in: $26^{\text {th }}$ International Conference on Optical Fiber Sensors, Lausanne, Switzerland, paper WF43. DOI: 10.1364/OFS.2018.WF43

Bridgeman, J., Baker, A., Carliell-Marquet, C., and Carstea, E. (2013). "Determination of changes in wastewater quality through a treatment works using fluorescence spectroscopy," Environmental Technology 34(23), 3069-3077. DOI:

10.1080/09593330.2013.803131

Carstea, E. M., Bridgeman, J., Baker, A., and Reynolds, D. M. (2016). "Fluorescence spectroscopy for wastewater monitoring: A review," Water Research 95, 205-219. DOI: $10.1016 /$ j.watres.2016.03.021

Çeçen, F. (2003). "The use of UV-VIS measurements in the determination of biological treatability of pulp bleaching effluents," in: Conf. Proc. - $7^{\text {th }}$ International Water Association Symposium on Forest Industry Wastewaters, Seattle, WA, pp. 135-142.

CEMA Resolution 070/2009 (2009). "Dispõe sobre o licenciamento ambiental, estabelece condições e critérios e dá outras providências, para empreendimentos industriais [Provides for environmental licensing, establishes conditions and criteria and provides other measures for industrial enterprises]," Paraná - Governo do Estado, Curitiba, Paraná, Brazil.

CEMA Resolution 081/2010 (2010). “Dispõe sobre critérios e padrões de ecotoxicidade para o controle de efluentes líquidos lançados em águas superficiais no estado do Paraná [Provides for ecotoxicity criteria and standards for the control of liquid effluents discharged into surface waters in the state of Paraná]," Paraná - Governo do Estado, Curitiba, Paraná, Brazil.

Chamorro, S., Pozo, Z., Jarpa, M., Hernandes, V., Becerra, J., and Vidal, G. (2009). "Monitoring endocrine activity in kraft mill effluents treated by an aerobic moving bed bioreactor system," Water Science and Technology 62(1), 154-161. DOI: 10.2166/wst.2010.297

Chandra, R., Singh, R., and Yadav, S. (2012). "Effect of bacterial inoculum ratio in mixed culture for decolorization and detoxification of pulp paper mill effluent," Journal of Chemical Technology \& Biotechnology 87(3), 436-444. DOI: $10.1002 /$ jctb. 2758

Chandra, R., Singh, S., Reddy, M. M. K., Patel, D. K., Purohit, H. J., and Kapley, A. (2008). "Isolation and characterization of bacterial strains Paenibacillus sp. and Bacillus sp. for kraft lignin decolorization from pulp and paper mill waste," The Journal of General and Applied Microbiology 54(6), 399-407. DOI: 10.2323/jgam.54.399

Duarte, J. C., Peitz, P., and Xavier, C. R. (2018). “Avaliação do tratamento de efluente kraft com meio de suporte esponjoso em reator sequencial em batelada (RSB) [Evaluation of the treatment of kraft effluent with spongy support medium in 
sequential batch reactor]," in: Anais XIV Simpósio Ítalo-Brasileiro de Engenharia Sanitária Ambiental - SIBESA, Foz do Iguaçu, Brazil.

Ghribi, M., Meddeb-Mouelhi, F., and Beauregard, M. (2016). "Microbial diversity in various types of paper mill sludge: Identification of enzyme activities with potential industrial applications," Springer Plus 5, 1492. DOI: 0.1186/s40064-016-3147-8

Hooda, R., Bhardwaj, N. K., and Singh, P. (2018). "Brevibacillus parabrevis MTCC 12105: A potential bacterium for pulp and paper effluent degradation," World Journal of Microbiology and Biotechnology 34(2), 31-41. DOI: 10.1007/s11274-018-2414-y

Hossain, K., and Ismail, N. (2015). "Bioremediation and detoxification of pulp and paper mill effluent: A review," Research Journal of Environmental Toxicology 9(3), 113 134. DOI: $10.3923 /$ rjet.2015.113.134

Hubbe, M. A., Metts, J. R., Hermosilla, D., Blanco, M. A., Yerushalmi, L., Haghighat, F., Lindholm-Lehto, P., Khodaparast, K., Kamali M., and Elliott, A. (2016).

"Wastewater treatment and reclamation: A review of pulp and paper industry practices and opportunities," BioResources 11(3), 7953-8091. DOI:

10.15376/biores.11.3. 7953-8091

IBÁ - Indústria Brasileira de Árvores. (2020). "Relatório IBÁ 2020,"

(https://iba.org/datafiles/publicacoes/relatorios/relatorio-iba-2020.pdf), Accessed 22 October 2020.

Janhom, T., Pavasant, P., and Wattanachira, S. (2011). "Profiling and monitoring of DOM in brewery wastewater and treated wastewater," Environmental Monitoring and Assessment 176, 403-418. DOI: 0.1007/s10661-010-1592-3

Jordão, E. P. and Pessoa, C. A. (2016). Tratamentos de Esgotos Domésticos [Domestic Sewage Treatments], ABES, Rio de Janeiro, Brazil.

Kamali, M., Alavi-Borazjani, S. A., Khodaparast, Z., Khalaj, M., Jahanshahi, A., Costa, E., and Capela, I. (2019). "Additive and additive-free treatment technologies for pulp and paper mill effluents: advances, challenges and opportunities," Water Resources and Industry 21, 100109. DOI: 10.1016/j.wri.2019.100109

Kamali, M., and Khodaparast, Z. (2015). "Review on recent developments on pulp and paper mill wastewater treatment," Ecotoxicology Environmental Safety 114, 326-342. DOI: 10.1016/j.ecoenv.2014.05.005

Lewis, R., Cohen, J., Awad, J., Burger, H., Marzouk, J., Burch, G., Lewis, D. M., and Van Leeuwen, J. A. (2018). "Study of the impacts of process changes of a pulp and paper mill on aerated stabilization basin (ASB) performance," Chemosphere 211, 767-774. DOI: 10.1016/j.chemosphere.2018.07.178

Machado, E. P., Xavier, C. R., and Couto, G. H. (2018). “Tratamento de efluente Kraft em lagoa aerada facultativa empregando enzimas lignolíticas [Kraft effluent treatment in an optional aerated lagoon using lignolytic enzymes]," Interciencia 43(8), 590-596.

Majumdar, S., Priyadarshinee, R., Kumar, A., Mandal, T., and Mandal, D. D. (2019). "Exploring Planococcus sp. TRC1, a bacterial isolate, for carotenoid pigment production and detoxification of paper mill effluent in immobilized fluidized bed reactor," Journal of Cleaner Production 211, 1389-1402. DOI:

10.1016/j.jclepro.2018.11.157

Managó, B. (2019). Treatment of Pulp Wastewater by Membrane Bioreactor, Ph.D. Dissertation, Universidade Estadual do Centro-Oeste, Irati, Paraná, Brazil.

Melchiors, E. (2019). Avaliação do Desenvolvimento de Biofilme em Meio Suporte Esponjoso em Reator Biológico de Leito Móvel (MBBR) no Tratamento de Efluente de Indústria de Celulose [Evaluation of the development of biofilm in spongy support 
medium in biological reactor of mobile bed (MBBR) in the treatment of effluent from the cellulose industry], Master's Thesis, Universidade Tecnológica Federal do Paraná - Curitiba, Paraná, Brazil.

Metcalf, L. and Eddy, H. P. (2016). Tratamento de Efluente e Recuperação de Recursos [Effluent Treatment and Resource Recovery], McGraw Hill Brasil, Porto Alegre, Brazil.

Murphy, K. R., Hambly, A., Singh, S., Henderson, R. K., Baker, A., Stuetz, R., and Khan, S. J. (2011). "Organic matter fluorescence in municipal water recycling schemes: toward a unified PARAFAC model," Environmental Science Technology 45(7), 2909-2916. DOI: 10.1021/es103015e

Peitz, C., and Xavier. C. R. (2020). "Moving bed biofilm reactor for treatment of kraft pulp effluent with high organic load rate," Revista Ambiente \& Água 15(4), 1-10. DOI: $10.4136 /$ ambi-agua.2512

Peitz, C. and Xavier. C. R. (2019). "Evaluation of aerated lagoon modified with spongy support medium treating kraft pulp mill efluent," Revista Facultad de Ingeniería Universidad de Antioquia 92, 70-79. DOI: 10.17533/udea.redin.20190725

Peitz, C. (2018). Desempenho de Sistema Modificado de Lagoa Aerada com Meio de Suporte em Leito Móvel no Tratamento de Efluente de Celulose Kraft [Performance of Modified Aerated Lagoon System with Mobile Bed Support Medium in Kraft Cellulose Effluent Treatment], Master's Thesis, Programa de Pós-Graduação em Ciência e Tecnologia Ambiental, Universidade Tecnológica Federal do Paraná, Curitiba, Paraná, Brazil.

Raj, A., Kumar, S., Haq, I., and Singh, S. K. (2014). "Bioremediation and toxicity reduction in pulp and paper mill effluent by newly isolated ligninolytic Paenibacillus sp.," Ecological Engineering 71, 355-362. DOI: 10.1016/j.ecoleng.2014.07.002

Saleem, M, Ahmad, S., and Ahmad, M. (2014). "Potential of Bacillus cereus for bioremediation of pulp and paper industrial waste," Annals of Microbiology 64(2), 823-829. DOI: 10.1007/s13213-013-0721-y

Singh, A. K., Yadav, P., Bharagava, R. N., Saratale, G. D., and Raj. A. (2019). "Biotransformation and cytotoxicity evaluation of kraft lignin degraded by ligninolytic Serratia liquefaciens," Frontiers in Microbiology 10, 2364. DOI: 10.3389/fmicb.2019.02364

Sonkar, M., Kumar, M., Dutt, D., and Kumar, V. (2019). “Treatment of pulp and paper mill effluent by a novel bacterium Bacillus sp. IITRDVM-5 through a sequential batch process," Biocatalysis and Agricultural Biotechnology 20, 101232.

Subashini, A. M. (2015). "Review on biological treatment processes of pulp and paper industry wastewater," International Journal of Innovative Research in Science, Engineering and Technology 4(5), 3721-3725. DOI:

10.15680/IJIRSET.2015.0405195

Swamy, N. K., Singh, P., and Sarethy, I. P. (2011). "Aerobic and anaerobic treatment of paper industry wastewater," Research in Environment Life and Science 4(4), 141-148.

Vicente, V. A., Attili-Angelis, D., Pie, M. R., Queiroz-Telles, F., Cruz, L. M., Najafzadeh, M. J., Hoog, G. S., Zhao J. S., and Pizziranikleiner, A. (2008). "Environmental isolation of black yeast-like fungi involved in human infection," Studies in Mycology 61, 137-144.

Von Sperling, M. (2016). Urban Wastewater Treatment in Brazil (IDB-TN-970), Department of Sanitary and Environmental Engineering, Federal University of Minas Gerais, Brazil. 
Von Sperling, M. (2014). "Introdução à qualidade das águas e ao tratamento de esgotos [Introduction to water quality and sewage treatment]," in: Princípios do tratamento biológico de águas residuárias [Principles of biological wastewater treatment], Belo Horizonte, Minas Gerais, Brazil.

Article submitted: March 20, 2021; Peer review completed: May 9, 2021; Revised version received and accepted: May 22, 2021; Published: June 1, 2021.

DOI: $10.15376 /$ biores.16.3.5203-5219 